\title{
Dichlorobis(cycloalkylamine)platinum(II) Complexes Structure Activity Relationship on the Human MDA-MB-231 Breast Cancer Cell Line**
}

\author{
J. Kritzenberger ${ }^{1, *}$, G. Bernhardt ${ }^{2}$, R. Gust ${ }^{2}$, P. Pistor ${ }^{2}$, H. Schönenberger ${ }^{2}$, \\ and $\mathbf{H}$. Yersin ${ }^{1}$ \\ 1 Institut für Physikalische und Theoretische Chemie, Universität Regensburg \\ 2 Institut für Pharmazie, Lehrstuhl Pharmazeutische Chemie II, Universität Regensburg, D-W-8400 \\ Regensburg, Federal Republic of Germany
}

Summary. The syntheses of dichlorobis(cycloalkylamine)platinum(II) complexes with cis and trans cycloalkylamine ligands $\left[\right.$ cis- $\mathrm{PtCl}_{2}\left(\mathrm{C}_{3} \mathrm{H}_{5} \mathrm{NH}_{2}\right)_{2}$ to cis- $\mathrm{PtCl}_{2}\left(\mathrm{C}_{8} \mathrm{H}_{15} \mathrm{NH}_{2}\right)_{2}$ (3-8) and trans- $\mathrm{PtCl}_{2}$ $\left(\mathrm{C}_{7} \mathrm{H}_{13} \mathrm{NH}_{2}\right)_{2}(9)$ and trans- $\left.\mathrm{PtCl}_{2}\left(\mathrm{C}_{8} \mathrm{H}_{15} \mathrm{NH}_{2}\right)_{2}(10)\right]$ are described. The distinction between cis and trans isomers was achieved by ${ }^{1} \mathrm{H}-\mathrm{NMR}$ spectroscopy. The antitumor activity was determined on the cell proliferation of the human MDA-MB-231 breast cancer cell line during long-term drug exposure. The complexes with small cycloalkylamine ligands (3-6) were inferior, those with large cycloalkylamine ligands were comparable (7) or superior (8) to cisplatin. Surprisingly, the cis/trans isomers $7 / 9$ and $\mathbf{8} / \mathbf{1 0}$ were equally active. All cycloalkylamine ligands were inactive. IR-spectroscopic studies showed that the size of the cycloalkylamine ring does not lead to significant differences in the $\mathrm{Pt}-\mathrm{Cl}$ binding strength. Therefore it is assumed that the markedly stronger antitumor activity of the higher homologues, 7-10, is not the result of a faster reaction with bionucleophils such as DNA. A possible explanation of the high activity of 7-10 is the strong lipophilicity of the complexes. This assumption was confirmed by toxicity tests against confluent cultures.

Keywords. cis- and trans-Dichlorobis(cycloalkylamine)platinum(II) complexes; Antitumor activity; MDA-MB-231 Breast cancer cell line.

Dichlorobis(cycloalkylamin)platin(II)-Komplexe. Struktur - Wirkungsbeziehungen an der menschlichen MDA-MB-231 Brustkrebszellinie

Zusammenfassung. Die Synthese von Dichlorobis(cycloalkylamin)platin(II)-Komplexen mit cis- und trans-ständigen Cycloalkylaminliganden $\left[\right.$ cis- $\mathrm{PtCl}_{2}\left(\mathrm{C}_{3} \mathrm{H}_{5} \mathrm{NH}_{2}\right)_{2}$ bis cis- $\mathrm{PtCl}_{2}\left(\mathrm{C}_{8} \mathrm{H}_{15} \mathrm{NH}_{2}\right)_{2}$ (3-8)

* Present address: Department of Chemistry, University of California, Berkeley, California 94720, U.S.A.

** In memory of Professor Dr. Günter Gliemann, late director of the Institut für Physikalische und Theoretische Chemie, Universität Regensburg. 
sowie trans- $\mathrm{PtCl}_{2}\left(\mathrm{C}_{7} \mathrm{H}_{13} \mathrm{NH}_{2}\right)_{2}$ (9) und trans- $\mathrm{PtCl}_{2}\left(\mathrm{C}_{8} \mathrm{H}_{15} \mathrm{NH}_{2}\right)_{2}$ (10)] wird beschrieben. Eine Unterscheidung zwischen cis- und trans-Isomeren konnte mit Hilfe der ${ }^{1} \mathrm{H}-\mathrm{NMR}$-Spektroskopie getroffen werden. Die tumorwachstumshemmende Wirkung wurde im Langzeitversuch an der menschlichen MDA-MB-231 Brustkrebszellinie bestimmt. Die Komplexe mit kleinen Cycloalkylaminliganden (3-6) waren weniger, diejenigen mit großen Cycloalkylaminliganden vergleichbar (7) oder besser (8) wirksam als Cisplatin. Überraschenderweise waren die cis/trans Isomeren 7/9 und 8/10 gleich aktiv. Sämtliche Cycloalkylaminliganden waren unwirksam. IR-spektroskopische Untersuchungen zeigen, daß die Größe des Cycloalkylaminliganden zu keiner signifikanten Veränderung der $\mathrm{Pt}-\mathrm{Cl}$ Bindungsstärke führt. Es wird angenommen, daß die deutlich stärkere Antitumoraktivität der höheren Homologen 7-10 nicht auf eine schnellere Reaktion mit Bionucleophilen wie der DNA zurückzuführen ist. Eine mögliche Erklärung der hohen Aktivität von 7-10 liegt in der starken Lipophilie der Komplexe. Diese Annahme wird durch Cytotoxizitätstests an stationären Kulturen gestützt.

\section{Introduction}

The synthesis of the homologous cis-dichlorobis(cycloalkylamine)platinum(II) complexes 3-8* and of the trans-isomers of 3-6 as well as their antitumor activity (against the ADJ/PC6 plasmacytoma of the mouse) have been described [1-3]. A simple correlation between activity and molecular size, which is known for homologous series of numerous drugs (e.g. antimicrobial agents), was not detectable. The first three homologues of the cis-series (3-5) proved to be equipotent. For a $90 \%$ inhibition of tumor growth, comparable doses were required (ID ${ }_{90} \approx$ $2.5 \mathrm{mg} / \mathrm{kg}$; cisplatin: $\mathrm{ID}_{90}=1.6 \mathrm{mg} / \mathrm{kg}$ ). To achieve the same effect with the higher homologues, approximately a 5-, 3-, or 100-fold dosage of compounds 6, 7, and 8, had to be applied. In accordance with these findings no continuous elevation of activity with increasing lipophilicity of the homologues was observed [2]. However, toxicity markedly decreased with growing ring size.

In contrast to the cis-configurated complexes 3-6, their trans isomers showed no or only marginal effects on the ADJ/PC6 tumor, which was ascribed to small amounts of the related cis-isomers contained in the probes [2]. In the study of Braddock et al. [2] compound 5, which in contrast to compound 6 was active against various tumor models (L1210 leukemia, Walker 256 carcinosarcoma), proved to be the most interesting representative. Due to its remarkable antitumor activity (ADJ/PC6: $\left.\mathrm{ID}_{90}=2.4 \mathrm{mg} / \mathrm{kg}\right)$ and its low toxicity $\left(\mathrm{ADJ} / \mathrm{PC} 6: \mathrm{LD}_{50}=\right.$ $480 \mathrm{mg} / \mathrm{kg}$ ), the therapeutic index** of this complex is more favorable than that of cisplatin (5: $\mathrm{TI}=200$; cisplatin: $\mathrm{TI}=8.1)$.

These interesting results prompted us to reevaluate the antitumor activity of the homologous cis-dichlorobis(cycloalkylamine)platinum(II) complexes (3-8). In this study the trans isomers of 7 and $\mathbf{8}$, whose tumor inhibiting properties were unknown, were included. The antitumor effect was determined on the human MDA-MB-231 breast cancer cell line by means of an in vitro chemosensitivity microassay described by Bernhardt et al. [4]. By this method the change of the growth curves of tumor cell lines under the influence of test compounds is registered. A kinetic assay yields more exact data on the antitumor activity than the conventional single-end-point

* The numbers of the compounds correspond to the size of the cycloalkylamine rings; compare Table 1.

** $\mathrm{TI}$ is defined as the ratio $\mathrm{LD}_{50} / \mathrm{ID}_{90}$. 
determination. In addition, it provides information on the mode of drug action, cytostatic or cytocidal, and on a possible development of secondary resistance [4]. The crystal violet staining technique used provides a measure for the reproductive potential of the culture. The results obtained in this test series are used to discuss the structure activity relationship of the complexes.

In the pharmacological experiments described by Connors et al. [1-3] an exact analysis of the used complexes by spectroscopic methods allowing the unequivocal assignment to the cis- or trans-series is missing. So we have also reconsidered the configuration and the isomeric purity of the cis-dichlorobis(cycloalkylamine)platinum(II) complexes 3-8 using ${ }^{1} \mathrm{H}-\mathrm{NMR}$-, IR-, Raman- and UV-vis-spectroscopy, as well as $\mathrm{X}$-ray diffractometry $[5,6]$.

\section{Experimental Part}

Reagents were used in the highest commercially available purity: Cyclopropylamine (Merck, $>98 \%$ ), cyclobutylamine (Aldrich, 98\%), cyclopentylamine (Merck, 99\%), cyclohexylamine (Aldrich, $>99 \%$ ), cycloheptylamine (Aldrich, 99\%), cyclooctylamine (EGA, 99\%), $\mathrm{K}_{2} \mathrm{PtCl}_{4}$ (Degussa, 46.75\% Pt), potassium iodide (Merck, p.a.), potassium chloride (Merck, p.a.), silver nitrate (Merck, p.a.), dimethylformamide (Merck, $>99.8 \%$ ).

\section{Synthesis Procedures}

Method A [7] (Scheme 1):

$\mathrm{K}_{2} \mathrm{PtCl}_{4}\left(0.422 \mathrm{~g}, 1.02 \times 10^{-3} \mathrm{~mol}\right)$ and $\mathrm{KI}\left(0.678 \mathrm{~g}, 4.08 \times 10^{-3} \mathrm{~mol}\right)$ were dissolved in bidistilled water $(10 \mathrm{ml})$ and stirred at room temperature for $\approx 3 \mathrm{~h}$. Then cyclopropylamine $\left(0.116 \mathrm{~g}, 2.03 \times 10^{-3} \mathrm{~mol}\right)$ was added. After $1 \mathrm{~h}$ the yellow cis-bis(cyclopropylamine)diiodoplatinum(II) precipitated and was filtered off. To change the leaving groups, the diiodoplatinum(II) complex was stirred in $21 \mathrm{ml}$ of a 0.1 $M$ aqueous silver nitrate solution ( $p H \approx 2.5$ ) for $12 \mathrm{~h}$. Precipitated $\mathrm{AgI}$ was removed by filtration, and $\mathrm{KCl}\left(0.152 \mathrm{~g}, 2.04 \times 10^{-3} \mathrm{~mol}\right)$ was added to the filtered solution. The mixture was kept in a refrigerator at $6^{\circ} \mathrm{C}$ for two days. The pale yellow product 3 was filtered off, washed with small amounts of water, methanol, and diethyl ether, and dried under vacuum. Yields are summarized in Table 2.

Method B [1]:

$\mathrm{K}_{2} \mathrm{PtCl}_{4}\left(0.3478 \mathrm{~g}, 8.38 \times 10^{-4} \mathrm{~mol}\right)$ was dissolved in bidistilled water $(10 \mathrm{ml})$. Then cyclobutylamine $\left(0.104 \mathrm{~g}, 1.46 \times 10^{-3} \mathrm{~mol}\right)$ was added $(p H \approx 8.2)$. The mixture was stirred at room temperature for $\approx 2 \mathrm{~h}$. The pale yellow product 4 was filtered off, washed with water, methanol and diethyl ether, and dried under vacuum. Yields are summarized in Table 2.

Method C:

Preparation of the trans compounds was based on the tendency of the complexes to interconvert in solution. The mixture of cis and trans compounds obtained by the preparation of dichlorobis(cycloheptylamine)platinum(II) according to method $\mathrm{B}\left(\mathrm{K}_{2} \mathrm{PtCl}_{4}: 0.403 \mathrm{~g}, 9.71 \times 10^{-4} \mathrm{~mol}\right.$; cycloheptylamine: $0.192 \mathrm{~g}, 1.7 \times 10^{-3} \mathrm{~mol}$ ) was dissolved in $D M F$. The solvent was allowed to evaporate spontaneously within two months. The residing solid product was washed with water, methanol, and diethyl ether, and dried under vacuum. Yields are summarized in Table 2.

\section{Spectroscopic Methods}

${ }^{1} \mathrm{H}-\mathrm{NMR}$ spectra were recorded on a PFT-NMR spectrometer (Bruker, model WM250) at $250 \mathrm{MHz}$. Dimethylformamide- $d_{7}$ was used as solvent. The powder diffraction spectra were recorded with a 
focusing monochromatic transmission diffractometer (STOE, model STADI P). IR spectra were recorded with a FTIR spectrometer (NICOLET, model $60 \mathrm{SX}$ ); resolution was set to $4 \mathrm{~cm}^{-1}$.

\section{MDA-MB-231 Human Breast Cancer Cell Line and Culture Conditions}

The MDA-MB-231 human breast cancer cell line [8] (ATCC no. HTB 26) was obtained from the American Type Culture Collection (ATCC, Rockville, MD, USA). Cells were grown in a humified atmosphere of $5 \% \mathrm{CO}_{2}$ at $37^{\circ} \mathrm{C}$ in $\mathrm{McCoy} 5 \mathrm{a}$ medium (Sigma), containing $\mathrm{NaHCO}_{3}(2.2 \mathrm{~g} / \mathrm{l})$, gentamicin $(40 \mu \mathrm{g} / \mathrm{ml}, \mathrm{Gibco})$ and $10 \%$ newborn calf serum (Gibco). The cells were harvested with trypsin $(0.05 \%) /$ EDTA $(0.02 \%)$ (Boehringer).

\section{Drugs}

Cisplatin (gold label) was purchased from Aldrich, carboplatin, 2,4-dinitrophenol (DNP) and rotenone from Sigma.

For chemosensitivity testing the cycloalkylamine ligands, the compounds $\mathbf{3}-\mathbf{1 0}$ and cisplatin were dissolved in spectrophotometric grade DMF (Aldrich). $D N P$ and rotenone were dissolved in p.a. EtOH (Merck), whereas carboplatin solutions were prepared with millipore filtered water.

\section{Chemosensitivity Assays}

\section{Determination of Drug Effects on Proliferating Cultures}

Two test series were carried out. The platinum complexes were assayed in passage 87 , the cycloalkylamine ligands in passage 146 . The cells were plated $(100 \mu \mathrm{l} /$ well $)$ in 96 -well microplates at a density of about $19 \mathrm{cells} /$ microscopic field (Leitz Diavert, $320 \times$ ) and were allowed to attach. After 3 days, the medium was removed by suction and replaced with fresh medium $(200 \mu 1 /$ well) containing drug (drugs were added as a 1000 -fold stock solution in $D M F$ ) or pure solvent. On every plate the rows 5 and $6(n=16)$ served as controls, whereas two vertical rows $(n=16)$ per drug concentration were used. After varying times of incubation the cells were fixed with glutaraldehyde and stored under PBS at $4{ }^{\circ} \mathrm{C}$. The PBS contained $\mathrm{NaCl}(8 \mathrm{~g}), \mathrm{KCl}(0.2 \mathrm{~g}), \mathrm{Na}_{2} \mathrm{HPO}_{4} \cdot 2 \mathrm{H}_{2} \mathrm{O}(1 \mathrm{~g}), \mathrm{NaH}_{2} \mathrm{PO}_{4} \cdot \mathrm{H}_{2} \mathrm{O}$ $(0.15 \mathrm{~g})$ and $\mathrm{KH}_{2} \mathrm{PO}_{4}(0.2 \mathrm{~g})$ in $11 \mathrm{H}_{2} \mathrm{O}$. All plates were stained with crystal violet simultaneously. The processing procedure and data analysis were performed as described by Reile et al. [9]. Drug effects were calculated as corrected $\mathrm{T} / \mathrm{C}$ values, defined according to:

$$
(\mathrm{T} / \mathrm{C})_{\text {corr }}(\%)=\left\{\left(\mathrm{T}-\mathrm{C}_{0}\right) /\left(\mathrm{C}-\mathrm{C}_{0}\right)\right\} \times 100
$$

where $\mathrm{T}$ is the absorbance $(578 \mathrm{~nm})$ of the treated cells, $\mathrm{C}$ the absorbance of the controls and $\mathrm{C}_{0}$ the absorbance at the time $(t=0)$ when drug was added.

Experimental errors of $(\mathrm{T} / \mathrm{C})_{\text {corr }}$ were calculated as described in [4] and are represented by error-bars in the figures.

\section{Determination of Drug Effects on Stationary Cultures}

To quantitate "basal" toxicity the cells (in passage 146) were seeded in microplates $(200 \mu \mathrm{l} / \mathrm{well})$ at a density of about 50 cells/field of vision $(320 \times)$. After 6 days, when the cultures had reached confluence (absorbance at $578 \mathrm{~nm}$ was about 2), the culture medium was replaced with $200 \mu \mathrm{l}$ of fresh medium containing drug or pure solvent, as described above. At the time points indicated in Fig. 7 the cells were fixed, stained and processed simultaneously at the end of the experiment.

The extent of drug induced cell kill, i.e. disintegration of the cells (cf. [4]), was calculated according to:

$$
\text { cell kill }(\%)=\left\{\left(\mathrm{C}_{0}-\mathrm{T}\right) / \mathrm{C}_{0}\right\} \times 100
$$

where $C_{0}$ is the mean absorbance of the culture when drug was added and $T$ the mean absorbance of the treated cells at varying times of drug exposure. 


\section{Results}

\section{Preparation and Characterization of the Complexes}

In square-planar complexes the coordination of one ligand to the metal ion influences the bonding between the metal ion and every other ligand [10-12]. This trans directing effect, a kinetic phenomenon, has extensively been used to prepare the isomeric forms of diamminedichloroplatinum(II). The cis isomer (cisplatin) is the product of the reaction of $\mathrm{K}_{2} \mathrm{PtCl}_{4}$ with aqueous ammonia buffered with $\mathrm{NH}_{4} \mathrm{Cl}$ [13], while trans-diamminedichloroplatinum(II) (transplatin) results from the reaction of $\left[\mathrm{Pt}\left(\mathrm{NH}_{3}\right)_{4}\right] \mathrm{Cl}_{2}$ with hydrochloric acid [13].

One has to be aware that besides the trans directing effect of the coordinating ligands, the size of the ligands determines the place of substitution. The thermodynamically stable form of the $\mathrm{PtCl}_{2} \mathrm{am}_{2}$ ( $\mathrm{am}=$ cycloalkylamine) complexes is the trans isomer [10]. Therefore, in aqueous $\mathrm{KCl}$ solution cisplatin undergoes a conversion from the cis to the trans isomer with a half-life of 1.8 years at $37^{\circ} \mathrm{C}$ [14].

The isomerization is more rapid when cycloalkylamines are used as ligands. Complex 4 shows a conversion to the trans isomer during the process of recrystallization [15]. Zanotti et al. [16] and Bradford et al. [17] tried to prepare crystals of 6 and 7, respectively. In each case the corresponding trans isomer was obtained. Therefore, for preparation of the $\mathrm{PtCl}_{2} a m_{2}$ complexes (3-10) (see Table 1), various synthetic routes must be employed (method A-C; Scheme 1).

We have used method A to prepare compounds 3,7 , and 8 , and method $B$ for compounds 4-6. The purity of the products (see Table 2) was verified by elemental analyses.

The coordination of the cycloalkylamines to platinum was confirmed by ${ }^{1} \mathrm{H}$-NMR spectroscopy. Due to the deshielding effect of the metal atom the coordination of the cycloalkylamines to platinum results in a low field shift of the NH signals. These signals can be used to assign the platinum complexes 3-10 either to the cis or the trans form. The ${ }^{1} \mathrm{H}-\mathrm{NMR}$ spectra of the complexes in the region typical for the NH resonance are shown in Fig. 1. Detailed ${ }^{1} \mathrm{H}-\mathrm{NMR}$ data are listed in Table 3.

For compounds 7 and $\mathbf{8}$ (with $a m=$ cycloheptylamine and cyclooctylamine, respectively) synthesized according to method $\mathrm{B}$ as described by Connors et al. [1], two resonances in the NH region were detectable, which could result either from different conformeric structures or a cis/trans isomer mixture. To exclude the

$$
\begin{aligned}
& \mathrm{K}_{2}\left[\mathrm{PtCl}_{4}\right]+4 \mathrm{KI} \stackrel{\mathrm{H}_{2} \mathrm{O}}{\longrightarrow} \mathrm{K}_{2}\left[\mathrm{PtI}_{4}\right]+4 \mathrm{KCl}
\end{aligned}
$$

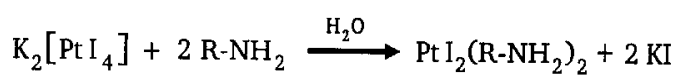

$$
\begin{aligned}
& \mathrm{PtI}_{2}\left(\mathrm{R}-\mathrm{NH}_{2}\right)_{2}+2 \mathrm{AgNO}_{3} \stackrel{\mathrm{H}_{2} \mathrm{O}}{\longrightarrow}\left[\mathrm{Pt}\left(\mathrm{H}_{2} \mathrm{O}\right)_{2}\left(\mathrm{R}^{-\mathrm{NH}_{2}}\right)_{2}\right]^{2+}+2 \mathrm{NO}_{3}^{-}+2 \mathrm{AgI} \\
& {\left[\mathrm{Pr}\left(\mathrm{H}_{2} \mathrm{O}\right)_{2}\left(\mathrm{R}-\mathrm{NH}_{2}\right)_{2}\right]^{2+}+2 \mathrm{Cl}^{-} \stackrel{\mathrm{H}_{2} \mathrm{O}}{\longrightarrow} \mathrm{PtCl}_{2}\left(\mathrm{R}-\mathrm{NH}_{2}\right)_{2}}
\end{aligned}
$$

Scheme 1. Preparation route according to method A [9] $\left(R-\mathrm{NH}_{2} \equiv\right.$ cycloalkylamine). The products $\mathrm{PtI}_{2}\left(R-\mathrm{NH}_{2}\right)_{2}, \mathrm{AgI}$, and $\mathrm{PtCl}_{2}\left(R-\mathrm{NH}_{2}\right)_{2}$ precipitate shifting the equilibrium far to the right 
Table 1. Dichlorobis(cycloalkylamine)platinum(II) complexes $\left[\mathrm{PtCl}_{2}\left(\mathrm{C}_{n} \mathrm{H}_{2 n-1}\right)_{2}\right]$ used in this study

\begin{tabular}{llll}
\hline Compound & $\mathrm{C}_{n} \mathrm{H}_{2 n-1}$ & $\begin{array}{l}\text { Leaving } \\
\text { group }\end{array}$ & $\begin{array}{l}\text { Geometric } \\
\text { configuration }\end{array}$ \\
\hline $\mathbf{3}$ & $\mathrm{C}_{3} \mathrm{H}_{5} \mathrm{NH}_{2}$ & $\mathrm{Cl}^{-}$ & cis \\
$\mathbf{4}$ & $\mathrm{C}_{4} \mathrm{H}_{7} \mathrm{NH}_{2}$ & $\mathrm{Cl}^{-}$ & cis \\
$\mathbf{5}$ & $\mathrm{C}_{5} \mathrm{H}_{9} \mathrm{NH}_{2}$ & $\mathrm{Cl}^{-}$ & cis \\
$\mathbf{6}$ & $\mathrm{C}_{6} \mathrm{H}_{11} \mathrm{NH}_{2}$ & $\mathrm{Cl}^{-}$ & cis \\
7 & $\mathrm{C}_{7} \mathrm{H}_{13} \mathrm{NH}_{2}$ & $\mathrm{Cl}^{-}$ & cis \\
$\mathbf{8}$ & $\mathrm{C}_{8} \mathrm{H}_{15} \mathrm{NH}_{2}$ & $\mathrm{Cl}^{-}$ & cis \\
$\mathbf{9}$ & $\mathrm{C}_{7} \mathrm{H}_{13} \mathrm{NH}_{2}$ & $\mathrm{Cl}^{-}$ & trans \\
$\mathbf{1 0}$ & $\mathrm{C}_{8} \mathrm{H}_{15} \mathrm{NH}_{2}$ & $\mathrm{Cl}^{-}$ & trans \\
compound 1 & Ecisplatin, cis- $\mathrm{Pt}\left(\mathrm{NH}_{3}\right)_{2} \mathrm{Cl}_{2}$ & & \\
compound 2 $\equiv$ carboplatin, cis- $\mathrm{Pt}\left(\mathrm{NH}_{3}\right)_{2}$ (cyclobutane-1,1-dicarboxylato) \\
\hline
\end{tabular}

Table 2. Analytical data of dichlorobis(cycloalkylamine)platinum(II) complexes

\begin{tabular}{llllllllll}
\hline Comp. & $\begin{array}{l}\text { Prep. } \\
\text { method }\end{array}$ & $\begin{array}{l}\text { Yield } \\
(\%)\end{array}$ & \multicolumn{2}{c}{$\mathrm{C}(\%)$} & \multicolumn{3}{c}{$\mathrm{H}(\%)$} & \multicolumn{3}{c}{$\mathrm{N}(\%)$} \\
\cline { 5 - 8 } & & & Calc. & Found & Calc. & Found & Calc. & Found \\
\hline $\mathbf{3}$ & A & 32 & 18.96 & 18.89 & 3.71 & 3.60 & 7.37 & 7.31 \\
$\mathbf{4}$ & B & 19 & 23.54 & 23.73 & 4.44 & 4.22 & 6.86 & 6.87 \\
$\mathbf{5}$ & B & 20 & 27.53 & 27.64 & 5.08 & 4.76 & 6.42 & 6.46 \\
$\mathbf{6}$ & B & 21 & 31.04 & 31.27 & 5.64 & 5.41 & 6.03 & 5.96 \\
$\mathbf{7}$ & A & 34 & 34.15 & 33.96 & 6.14 & 5.99 & 5.69 & 5.85 \\
$\mathbf{7}$ & B & 39 & 34.15 & 33.95 & 6.14 & 6.29 & 5.69 & 6.01 \\
$\mathbf{8}$ & A & 31 & 36.92 & 36.58 & 6.58 & 6.49 & 5.38 & 5.50 \\
$\mathbf{8}$ & B & 18 & 36.92 & 37.36 & 6.58 & 6.65 & 5.38 & 5.48 \\
$\mathbf{9}$ & C & 89 & 34.15 & 34.29 & 6.14 & 6.07 & 5.69 & 5.75 \\
$\mathbf{1 0}$ & C & 82 & 36.92 & 36.60 & 6.58 & 6.70 & 5.38 & 5.34 \\
\hline
\end{tabular}

presence of two different conformers, a temperature dependent ${ }^{1} \mathrm{H}-\mathrm{NMR}$ study was performed with 7. The two NH signals for dichlorobis(cycloheptylamine)platinum(II) (7) showed no change in intensity over the temperature range between 253 and $373 \mathrm{~K}$.

The trans-configuration of the side product of 7 (i.e., 9) was established by X-ray diffractometry. Using the atomic positions of trans-dichlorobis(cycloheptylamine)platinum(II) found by Bradford [17] we have calculated the expected powder diffractogram of this compound. The more intensive reflections of 9 were also found in the diagram of the cis-product 7, which we obtained with method B. Thus, the additional NH resonances visible in the ${ }^{1} \mathrm{H}-\mathrm{NMR}$ spectra of 7 and 8 synthesized by method B (Fig. 1) were assigned to the trans isomers 9 and 10. The high field shift of the NH signal of the trans compound, as compared to the shift of the cis isomer, is in good agreement with the values for the isomers of dichlorobis(pentane- 
compound

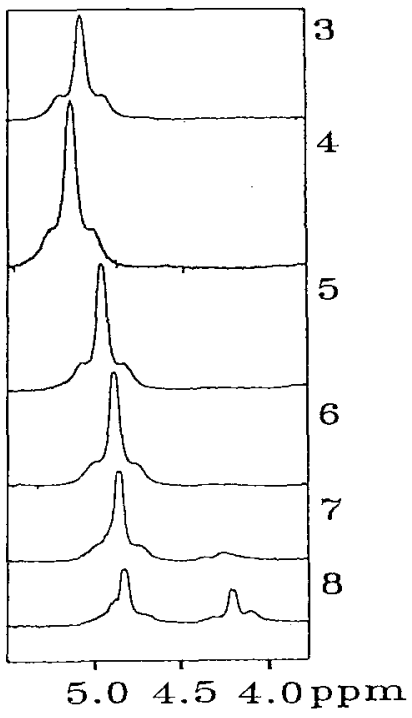

Fig. 1. ${ }^{1} \mathrm{H}-\mathrm{NMR}$ spectra of dichlorobis(cycloalkylamine)platinum(II) complexes $\left(250 \mathrm{MHz}, D M F-d_{7}\right)$. Compound 3 was prepared by method $\mathrm{A}$ and compounds $\mathbf{4}$ through $\mathbf{8}$ by method $\mathrm{B}$

1-amine)platinum(II) measured by Cherchi et al. [18]. From the integrals of the respective ${ }^{1} \mathrm{H}-\mathrm{NMR}$ signals, the ratio of the two isomeric forms of dichlorobis(cycloheptylamine)platinum(II) amounts to cis:trans $\approx 20: 1$, and for dichlorobis(cyclooctylamine)platinum(II) to cis:trans $\approx 2: 1$. The ratio of the cis/trans products depends on the ratio of the educts. The higher the concentration of the amine ligand, the higher the fraction of the trans isomer formed. In view of this result, we have used a molar ratio amine: $\mathrm{K}_{2} \mathrm{PtCl}_{4} \approx 1.75: 1$ for the preparation of the cis isomers ( 7 and 8 ) (Method B). Nonetheless, products 7 and 8 contained substantial amounts of the trans isomers.

Table 3. ${ }^{1} \mathrm{H}-\mathrm{NMR}$ data of dichlorobis(cycloalkylamine)platinum(II) complexes $\left(250 \mathrm{MHz}, D M F-d_{7}\right)$

\begin{tabular}{|c|c|c|c|c|}
\hline \multirow[t]{2}{*}{ Compound } & \multirow{2}{*}{$\begin{array}{l}\text { Prep. } \\
\text { method }\end{array}$} & \multicolumn{3}{|l|}{$\delta(\mathrm{ppm})$} \\
\hline & & $\mathrm{NH}$ & $\mathrm{CH}$ (methine) & $\mathrm{CH}$ (alkyl) \\
\hline 3 & A & $5.05(\mathrm{br}, 4 \mathrm{H})$ & $2.61(\mathrm{br}, 2 \mathrm{H})$ & $0.61-0.83(\mathrm{~s}, 8 \mathrm{H})$ \\
\hline 4 & $\mathrm{~B}$ & $5.13(\mathrm{br}, 4 \mathrm{H})$ & $3.68(\mathrm{br}, 2 \mathrm{H})$ & $1.53-2.36(\mathrm{~s}, 12 \mathrm{H})$ \\
\hline 5 & B & $4.96(\mathrm{br}, 4 \mathrm{H})$ & $3.55(\mathrm{br}, 2 \mathrm{H})$ & $1.45-2.19(\mathrm{~s}, 16 \mathrm{H})$ \\
\hline 6 & B & $4.89(\mathrm{br}, 4 \mathrm{H})$ & $2.92(\mathrm{br}, 2 \mathrm{H})$ & $0.98-2.53(\mathrm{~m}, 20 \mathrm{H})$ \\
\hline 7 & $\mathrm{~A}$ & $4.87(\mathrm{br}, 4 \mathrm{H})$ & $3.14(\mathrm{br}, 2 \mathrm{H})$ & $1.32-2.57(\mathrm{~m}, 24 \mathrm{H})$ \\
\hline \multirow[t]{2}{*}{7} & B & $4.88(\mathrm{br}, 3.8 \mathrm{H})$ & $3.17(\mathrm{br}, 2 \mathrm{H})$ & $1.33-2.53(\mathrm{~m}, 24 \mathrm{H})$ \\
\hline & & $4.27(\mathrm{br}, 0.2 \mathrm{H})$ & & \\
\hline 8 & A & $4.82(\mathrm{br}, 4 \mathrm{H})$ & $3.24(\mathrm{br}, 2 \mathrm{H})$ & $1.39-2.44(\mathrm{~m}, 28 \mathrm{H})$ \\
\hline \multirow[t]{2}{*}{8} & $\mathrm{~B}$ & $4.84(\mathrm{br}, 2.6 \mathrm{H})$ & $3.21(\mathrm{br}, 2 \mathrm{H})$ & $1.40-2.42(\mathrm{~m}, 28 \mathrm{H})$ \\
\hline & & $4.22(\mathrm{br}, 1.4 \mathrm{H})$ & & \\
\hline 9 & $\mathrm{C}$ & $4.25(\mathrm{br}, 4 \mathrm{H})$ & $3.05(\mathrm{br}, 2 \mathrm{H})$ & $1.33-2.42(\mathrm{~s}, 24 \mathrm{H})$ \\
\hline 10 & $\mathrm{C}$ & $4.24(\mathrm{br}, 4 \mathrm{H})$ & $3.15(\mathrm{br}, 2 \mathrm{H})$ & $1.38-2.41(\mathrm{~m}, 28 \mathrm{H})$ \\
\hline
\end{tabular}




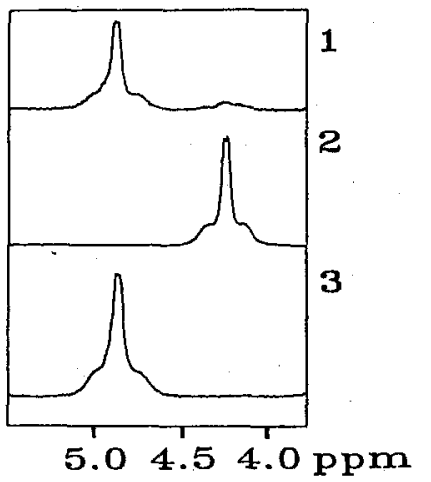

Fig. 2. ${ }^{1} \mathrm{H}-\mathrm{NMR}$ spectra of dichlorobis(cycloalkylamine)platinum(II) complexes ( $\left.250 \mathrm{MHz}, D M F-d_{7}\right)$. Trace (1): mixture of compounds 7 and 9 as obtained by preparation method B; trace (2): pure trans compound 9 prepared by method C; trace (3): pure cis compound 7 prepared by method A

Table 4. Coupling constants ${ }^{2} J_{\mathrm{Pt}-\mathrm{H}}$ of dichlorobis(cycloalkylamine)platinum(II) complexes

\begin{tabular}{lc}
\hline Compound & ${ }^{2} J_{\mathbf{P t}-\mathrm{H}}$ \\
\hline $\mathbf{3}$ & $66 \mathrm{~Hz}$ \\
$\mathbf{4}$ & $64 \mathrm{~Hz}$ \\
$\mathbf{5}$ & $65 \mathrm{~Hz}$ \\
$\mathbf{6}$ & $66 \mathrm{~Hz}$ \\
$\mathbf{7}$ & $66 \mathrm{~Hz}$ \\
$\mathbf{8}$ & $66 \mathrm{~Hz}$ \\
$\mathbf{9}$ & $54 \mathrm{~Hz}$ \\
$\mathbf{1 0}$ & $56 \mathrm{~Hz}$ \\
\hline
\end{tabular}

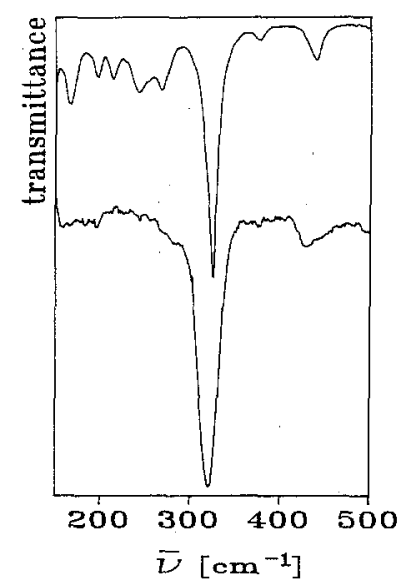

Fig. 3. IR spectra of the compounds 9 (upper trace) and 7 (lower trace)

According to Lock et al. [15] recrystallization of the compounds $\mathbf{7}$ and $\mathbf{8}$ in dimethylformamide yields compounds $\mathbf{9}$ and $\mathbf{1 0}$ due to a complete conversion into the corresponding trans isomers (method C).

For preparation of the pure cis isomers $\mathbf{7}$ and $\mathbf{8}$ we used the stronger trans directing effect of iodide compared to chloride [10-12]. Preparation using method A yielded the pure cis isomers of 7 and 8 . The ${ }^{1} \mathrm{H}-\mathrm{NMR}$ spectra of 7 and 9 obtained by methods $\mathrm{A}$ to $\mathrm{C}$ are shown in Fig. 2 . 
The values of ${ }^{195} \mathrm{Pt}-{ }^{1} \mathrm{H}$ coupling (Table 4) are in good agreement with those reported by $\mathrm{Ha}$ et al. [19], who found values of ${ }^{2} J_{\mathrm{Pt}-\mathrm{H}}=66.5 \pm 1.5 \mathrm{~Hz}$ (cis) and ${ }^{2} J_{\mathrm{Pt}-\mathrm{H}}=58 \pm 2 \mathrm{~Hz}$ (trans), respectively.

In earlier studies on this series of complexes, method B has been used exclusively to prepare the substances [1-3]. Our results indicate that a mixture of the cis and the trans isomers for compounds $\mathbf{7}$ and $\mathbf{8}$ is obtained when method B is applied. Elemental analysis, the analytical method used in Refs. [1-3] to demonstrate the purity of the products, is clearly not suitable to distinguish between the two isomers.

Braddock et al. [2] referred to IR absorptions in the region of the $\mathrm{Pt}-\mathrm{Cl}$ stretching vibrations to discriminate between the two isomers. Figure 3 shows the IR spectra of 7 and 9.

The cis compound (lower trace) exhibits a broad absorption with a maximum at $321 \mathrm{~cm}^{-1}$ and a half width of about $30 \mathrm{~cm}^{-1}$. The trans isomer (upper trace) gives rise to a sharp absorption at $326 \mathrm{~cm}^{-1}$ with a half width of $15 \mathrm{~cm}^{-1}$. From a comparison of the two spectra, we see that IR spectroscopy is not capable of tracing small amounts of the trans isomer present as an impurity in the cis isomer.

\section{Biological Tests}

\section{Effect of the Pt-Complexes on Proliferating Cultures}

The dichlorobis(cycloalkylamine)platinum(II) complexes $\mathbf{3}$ to $\mathbf{1 0}$ were tested on the human MDA-MB-231 breast cancer cell line. Cisplatin (1) and carboplatin (2) [cis-diamminecyclobutane-1,1-dicarboxylatoplatin(II)] were used as standards (see Fig. 4).

In order to provide the most information, the data are presented as corrected $\mathrm{T} / \mathrm{C}$ values (in \%) plotted versus time of drug exposure. An average growth curve
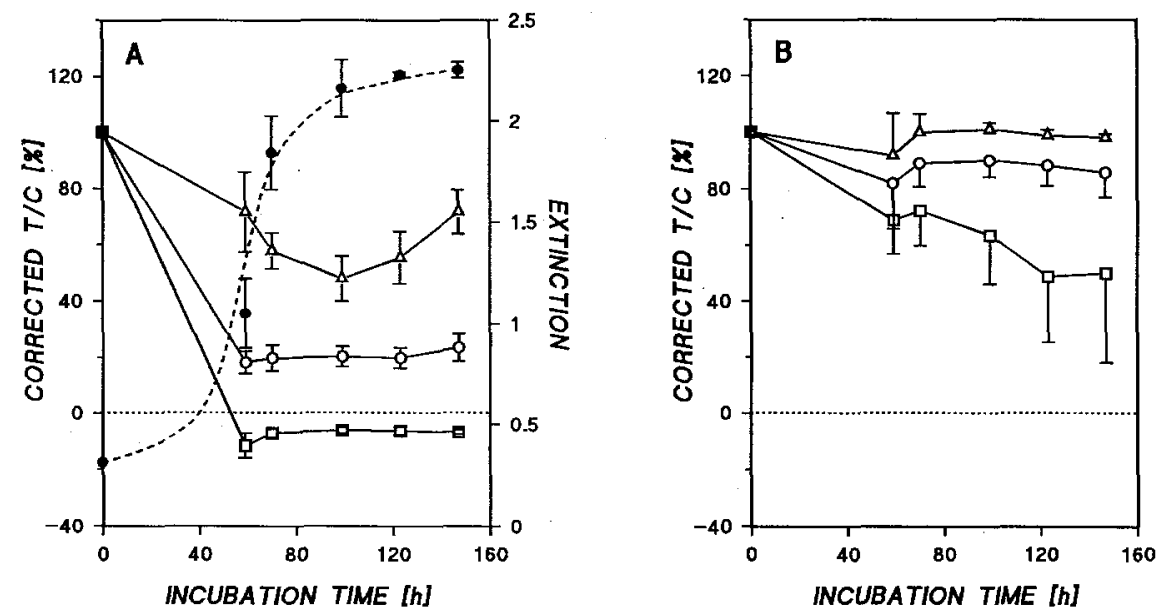

Fig. 4. A Effect of cisplatin on proliferating MDA-MB-231 cells: Plot of corrected $\mathrm{T} / \mathrm{C}$ values versus time of drug exposure, where $T$ is absorbance of treated cells and $C$ is that of the untreated $(\triangle, 1 \mu M ; O$, $5 \mu M ; \square, 10 \mu M)$; absorbance of the dimethylformamide controls. The values represent an average growth curve (dashed line) of all untreated cells. The error-bars represent the standard deviation of the mean. B Effect of carboplatin on proliferating MDA-MB-231 cells: Corrected T/C values as a function of incubation time $(\triangle, 1 \mu M ; O, 5 \mu M ; \square, 10 \mu M)$ 

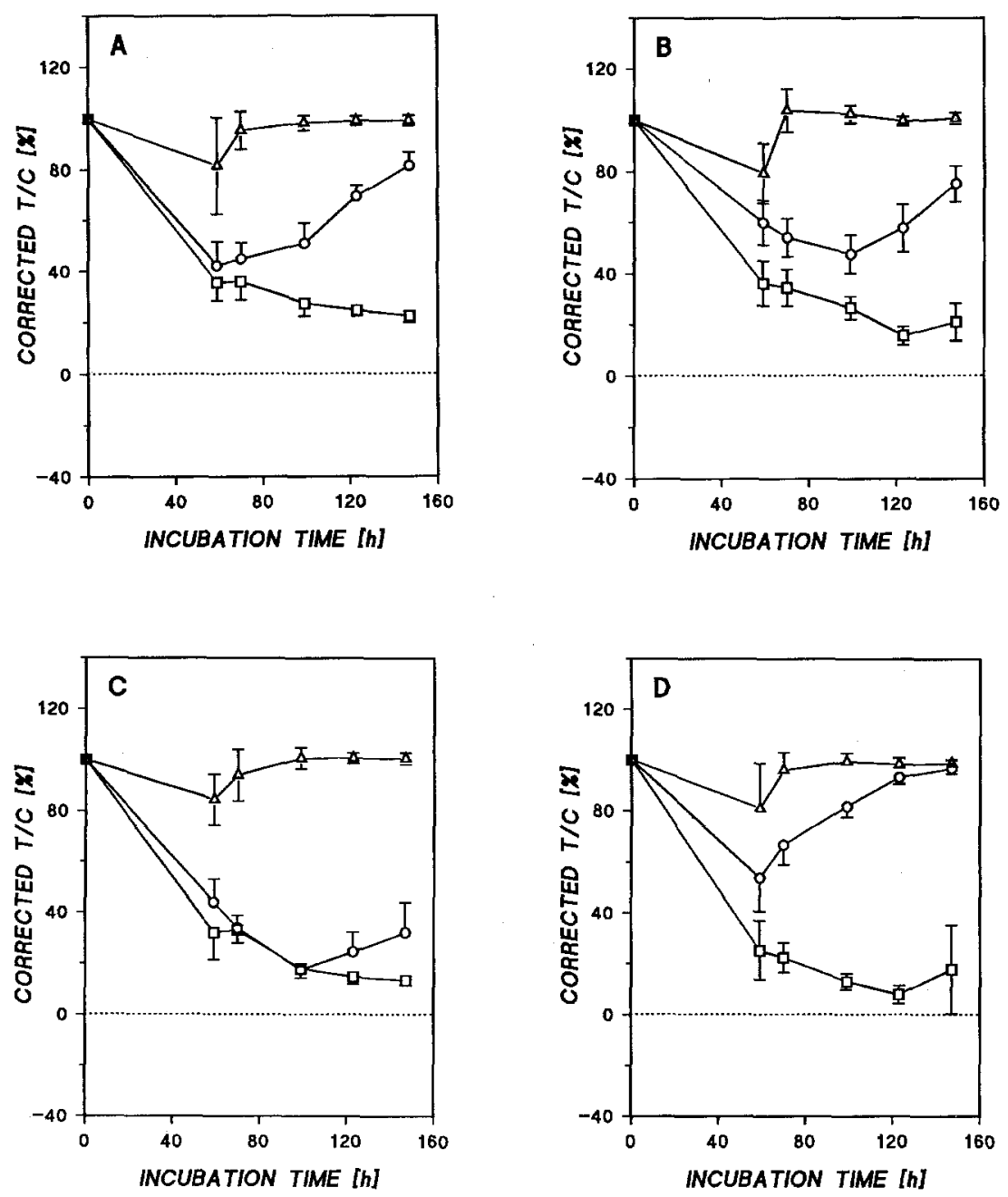

Fig. 5. Effect of compounds 3(A), 4(B), 5(C), and 6(D) on proliferating MDA-MB-231 cells: Corrected $\mathrm{T} / \mathrm{C}$ values are presented as a function of incubation time $(\triangle, 1 \mu M ; O, 5 \mu M ; \square, 10 \mu \mathrm{M})$

(absorbance plotted versus time) of the cells which were only exposed to the pure solvent is included in Fig. 4A. No change or an increase in $(\mathrm{T} / \mathrm{C})_{\text {corr }}(\%)$ values with time of drug exposure represent primary drug resistance. A gradual decrease in $(\mathrm{T} / \mathrm{C})_{\text {corr }}(\%)$ values with time indicates an inhibition of cell growth (i.e., a slowing down or a stopping of cell proliferation). When the control has reached the plateau phase parallelism of the $(\mathrm{T} / \mathrm{C})_{\text {corr }}(\%)$ curve with the $\mathrm{t}$-axes indicates cytostatic drug effects. Increasing $(\mathrm{T} / \mathrm{C})_{\text {corr }}(\%)$ values either reflect recovery of the cells from drug-induced damage, which may result in full reproductive integrity of the cultures (i.e., development of secondary resistance) or inactivation of the drug. $(\mathrm{T} / \mathrm{C})_{\text {corr }}(\%)$ values $<0$ indicate cytocidal drug action.

Figure 4A shows the effect of cisplatin (1) on the MDA-MB-231 breast cancer cell line. At the lowest concentration $(1 \mu M)$ the maximum inhibition of the cells was $\approx 50 \%$ after $99 \mathrm{~h}$. After $147 \mathrm{~h}$ (the last time point of cell growth determination) the cells recovered up to $\approx 70 \%$ of the net cell proliferation of the control at the end of 

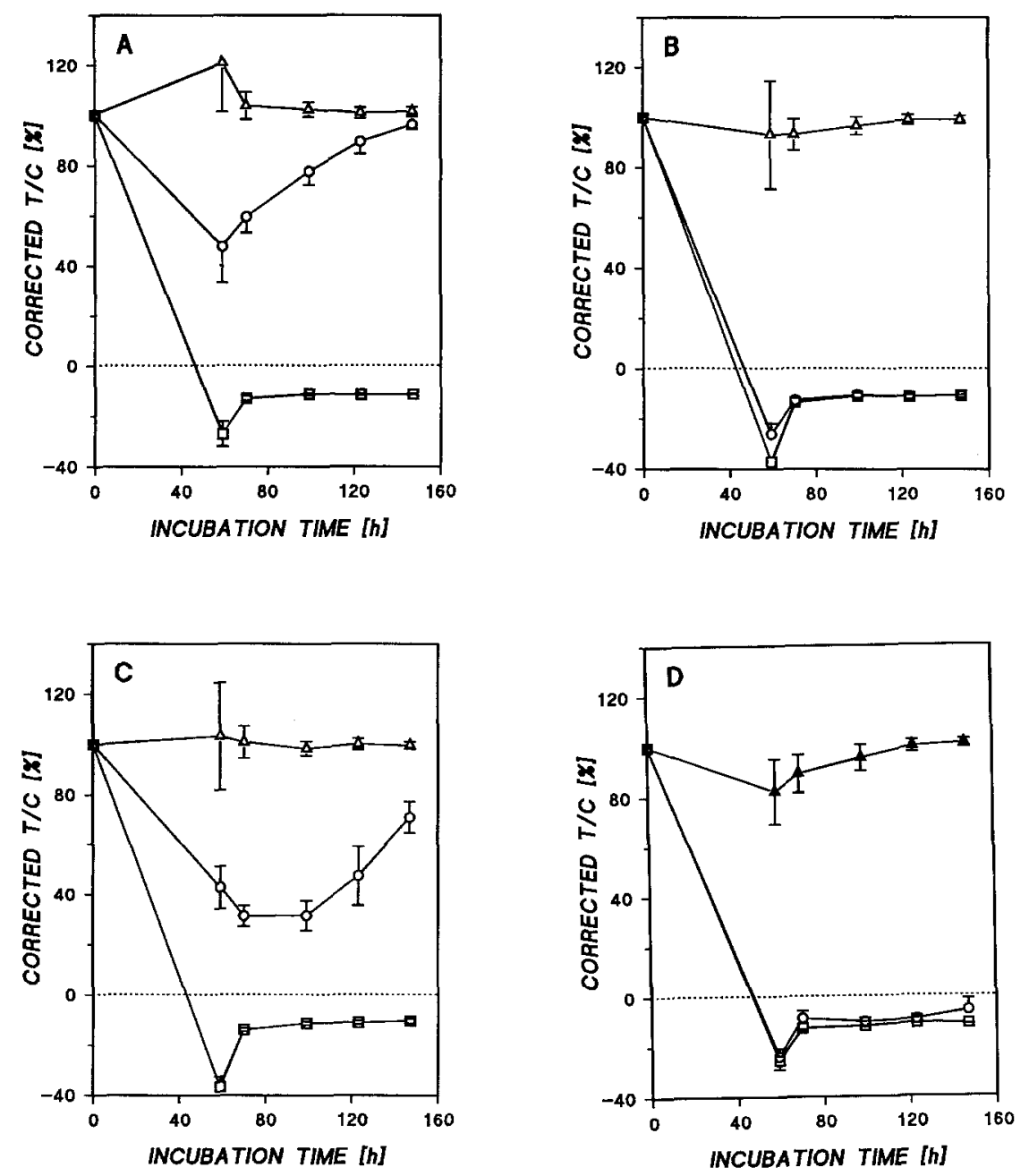

Fig. 6. Effect of compounds 7 (A), 8 (B), 9 (C), and 10 (D) on proliferating MDA-MB-231 cells: Corrected $\mathrm{T} / \mathrm{C}$ values are presented as a function of incubation time $(\triangle 1 \mu M ; \bigcirc, 5 \mu M ; \square, 10 \mu M)$

this experiment. With increasing cisplatin concentration, a clear dose-dependent inhibition was observed.

Carboplatin (2) shows an inhibition of $\approx 49 \%$ after $123 \mathrm{~h}$ only at the highest concentration (see Fig. 4B). These experimental result confirms the fact that cisplatin is 10 times more effective than carboplatin (at an equimolar dose).

In the cis-series, compounds 3 to $\mathbf{6}$ show a very similar behaviour in the tests against the MDA-MB-231 cell line (see Fig. 5). Their inhibitory effects lie between those of cisplatin and of carboplatin, respectively.

In each case, no inhibition was observed for the lowest concentration $(1 \mu M)$ used in the experiment. Higher concentrations induce dose dependent (except compound 5) inhibition of cell proliferation resulting in a cytostatic drug effect at the $10 \mu M$ concentration. At the highest concentration $(10 \mu M)$ the maximum effect does not increase significantly with the number of carbon atoms in the cycloalkylamine ligand. Compound 3 shows a maximum inhibition of $\approx 78 \%, 4$ of $\approx 84 \%, 5$ 

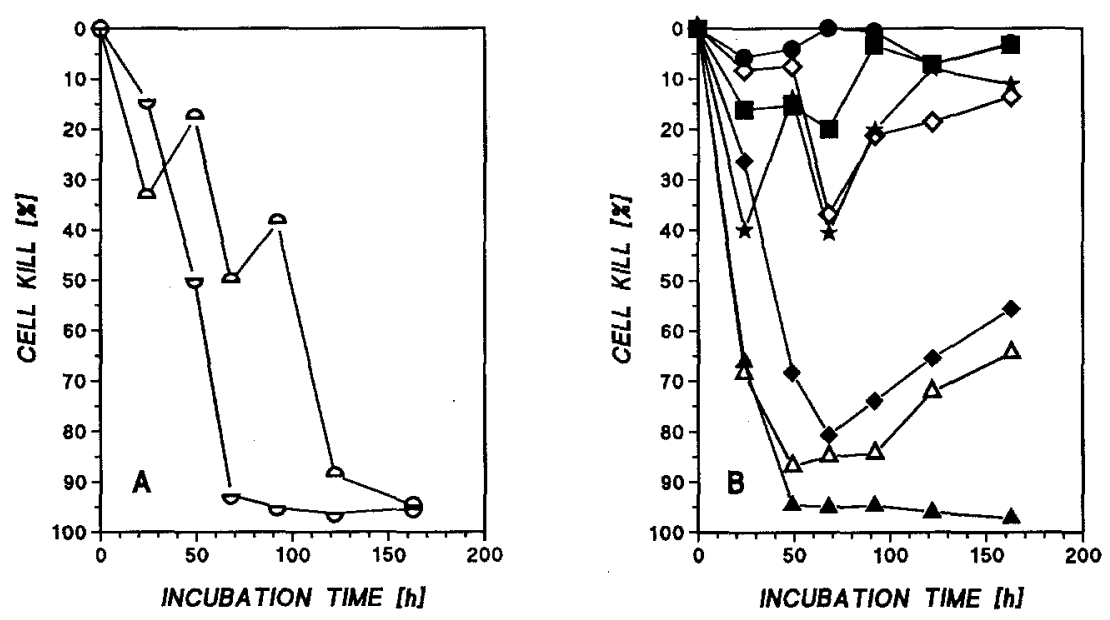

Fig. 7. Effect of inhibitors ATP synthesis and platinum complexes on non-proliferating MDA-MB-231 cells. In contrast to routine chemosensitivity testing, the drugs were added to confluent cultures and the kinetics of cell death was monitored. A ( ○) $100 \mu M$ 2,4-dinitrophenol; ( 0 ) $0.5 \mu M$ rotenone. B All platinum complexes were assayed at a concentration of $10 \mu \mathrm{mols} / 1 .\left(^{*}\right)$ cisplatin; compounds $(\bullet) \mathbf{5}$; $(\square) 6 ;(\bullet) 7 ;(\Delta) 8 ;(\diamond) 9 ;(\triangle) 10$

of $\approx 86 \%$, and 6 of $\approx 92 \%$. Similarly, at the $5 \mu M$ concentration the antitumor effect of 3-6 does not depend clearly on the size of the cycloalkyl ring. All compounds show comparable activities. Treated cells recover after $99 \mathrm{~h}(\mathbf{4}, \mathbf{5})$ or even earlier $(3$, 6), which indicates either inactivation of the drug or development of secondary drug resistance.

The enlargement of the ring size of the cycloalkylamine ligands to 7 or 8 carbon atoms leads to very active cis-dichlorobis(cycloalkylamine)platinum(II) complexes (7 and 8), which even produced cytocidal effects at concentrations as low as $5 \mu M$ (8) and $10 \mu M(7)$ (Fig. 6, A and B).

The comparative testing of the corresponding trans isomers ( 9 and 10) yielded unexpected results. Isomer 9 was similarly active as 7 , and the activity of trans isomer 10 was virtually the same as the one of 8 . At $1 \mu M$ and $10 \mu M$, respectively, the inhibition curves of the isomeric dichlorobis(cycloheptylamine)platinum(II) complexes ( 7 and 9) are comparable. A concentration of $5 \mu M$ reveals an even higher activity of the trans-compound 9, in comparison with the cis-compound 7 . Compound 9 gives rise to a minimum $(\mathrm{T} / \mathrm{C})_{\text {corr }}$-value of $\approx 30 \%\left[7:(\mathrm{T} / \mathrm{C})_{\text {corr }} \approx 50 \%\right]$. However, a recovery of the cells is observed after $59 \mathrm{~h}$ of drug cell contact with 7 , and after $99 \mathrm{~h}$ with 9 . Regarding the isomeric dichlorobis(cyclooctylamine)platinum(II)-complexes, no difference is detectable between cis and trans compounds at a concentration of $5 \mu \mathrm{M}$. In contrast to cisplatin, which produced cytocidal effects at a concentration of $10 \mu M$, both isomers (8 and 10) showed extremely steep dose response relationship being cytocidal already in the $5 \mu M$ concentration (Fig. 6B and D).

\section{Effect of the Cycloalkylamine Ligands on Proliferating Cultures}

To exclude the possibility that the higher cycloalkylamines alone were responsible for the above described antiproliferative activities, the ligands (cyclopentyl- to 
cyclooctylamine) were tested in an analogous assay. Proliferating MDA-MB-231 cells were incubated with ligand $(10$ and $20 \mu \mathrm{mols} / 1$, corresponding to the 5 and $10 \mu M$ concentration of the Pt-complexes) for $217 \mathrm{~h}$. $D M F$ was used as control and cisplatin as standard anticancer drug. Whereas cisplatin inhibited cell proliferation at the expected extent, none of the ligands did influence the growth curve significantly (data not shown). In other words, the members of the homologous cycloalkylamine series (pentyl to octyl) proved to lack antitumor activity at the concentrations tested.

\section{Effect of the Pt-Complexes of Stationary Cultures}

To determine "basal" toxicity on resting cells (usually not the target of anticancer drugs) plateau-phase cultures of MDA-MB-231 were treated with $10 \mu M$ cisplatin and those dichlorobis(cycloalkylamine)platinum(II) complexes (5-10), which were active against proliferating breast cancer cells. "Cell-death-kinetics" were registered for $163 \mathrm{~h}$ using the crystal violet procedure. Because of their cell cycle independent toxicity $100 \mu M 2,4$-dinitrophenol $D N P$ (an uncoupling agent) and $0.5 \mu M$ rotenone (a powerful inhibitor of electron transport) were chosen for comparison. As shown in Fig. 7A both inhibitors of mitochondrial function finally lead to cell death of the whole population. Microscopic observation revealed that values around $95 \%$ reflect disintegration of all cells in the culture. The $5 \%$-remainder originates from dye-retaining cell debris. In comparison with rotenone cell kill by $D N P$ was faster.

The results for the platinum complexes are summarized in Fig. 7B. Whereas only marginal toxicity was observed for cisplatin and the compounds 5 and $\mathbf{6}$, the cis-isomers 7 and 8 caused rapid cell death. Compound 8 was obviously most toxic, since all cells were already disintegrated after $50 \mathrm{~h}$ of drug exposure. At the same time cis-dichlorobis(cycloheptylamine)platinum(II) caused about $85 \%$ cell kill, but during the course of the experiment the culture partly recovered. This recovery of remaining cell populations can be explained by depletion and inactivation of the platinum complexes by reaction with cell surface constituents and biomolecules released in large amounts by dead cells.

In contrast to the inhibition of cell proliferation, where the corresponding cis- and trans-isomers $(7 / 9 ; 8 / 10)$ were almost equiactive (cf. Fig. 6A-D), the toxicity of the complexes with trans-geometry $(\mathbf{9}$ and $\mathbf{1 0})$ against non-proliferating cells was much lower (cf. Fig. 7B).

\section{Discussion}

The homologous cis-dichlorobis(cycloalkylamine)platinum(II) complexes (3-8) and the trans-isomers of 7 and 8 (i.e. compounds 9 and 10; concerning their structures compare Table 1) were synthesized, and the relative positions of their amine ligands (cis or trans) were confirmed by ${ }^{1} \mathrm{H}-\mathrm{NMR}$ spectroscopy. To investigate the influence of the ring size as well as of the coordination geometry (cis or trans) of the two cycloalkylamine ligands on the antitumor activity, compounds 3-10 were tested on the human MDA-MB-231 breast cancer cell line in vitro. Cisplatin and carboplatin were used as standards. As expected, carboplatin exhibited a markedly lower antitumor activity than cisplatin, which produced even cytocidal effects at a concentration of $10 \mu M\left[(\mathrm{~T} / \mathrm{C})_{\text {corr }}=-11.6\right]$. These considerable differences in 
activity between the two compounds are caused by the much slower formation of the active diamminediaquaplatinum(II) species in the case of carboplatin. The exchange of the leaving groups by $\mathrm{H}_{2} \mathrm{O}$ molecules is strongly delayed for the cyclobutane-1,1-dicarboxylato moiety (carboplatin) compared to chloride (cisplatin). The antitumor effect of the cis isomers, 3-8, depends on the size of the cycloalkyl ring. This influence is most obvious from the sudden rise in activity from the cyclohexylamine derivative 6 to the cycloheptyl- and cyclooctylamine derivatives ( 7 and 8). The complexes $\mathbf{7}$ and $\mathbf{8}$ are causing even cytocidal effects when used in concentrations as low as $5 \mu M(\mathbf{8})$ or $10 \mu M$ (7 and 8). Cis-dichlorobis(cyclooctylamine)platinum(II) (8) proved to be even more active than cisplatin. Within the group of homologues 3-6, the differences with regard to the inhibitory effect are less pronounced.

In contrast to our results, Connors and coworkers [1-3] have identified dichlorobis(cyclopentylamine)platinum(II) (5) as the most interesting representative of the cis-series (compounds 3-8). Compound $\mathbf{5}$ showed activity on a spectrum of rodent transplantation tumors which are also influenced by cisplatin. However, the toxicity of $\mathbf{5}$ is much lower and its therapeutic index considerably higher than the corresponding values of cisplatin. These properties distinguished the complex $\mathbf{5}$ as a candidate for a clinical evaluation.

In the study of Braddock et al. [2] compound 8, the most active representative of our in vitro test-series, was only effective in vivo when administered in extremely high dose $\left(\mathrm{ADJ} / \mathrm{PC} 6 ; \mathrm{ID}_{90}=230 \mathrm{mg} / \mathrm{kg}\right)$. Presumably, the weak in vivo effect of 8 is caused by its special pharmacokinetical behaviour resulting from a very low water solubility and a high lipophilicity.

In the following paragraphs we would like to discuss the possibility that the unequal antitumor activities of 3-8 could also be due to differences in the hydrolysis kinetics. Dichloroplatinum(II) complexes are non-reactive "prodrugs", which exert their antitumor effects after hydrolysis into the reactive species $\left.>\mathrm{PtCl}\left(\mathrm{H}_{2} \mathrm{O}\right)\right]^{+}$and especially $\left.>\mathrm{Pt}\left(\mathrm{H}_{2} \mathrm{O}\right)_{2}\right]^{2+}[20]$. The latter aqua-complex is preferentially bonded to the N7 nitrogen atoms of neighboring guanine bases in one DNA strand, resulting in intrastrand crosslinks. It is generally accepted that intrastrand crosslinks are responsible for the inhibition of DNA synthesis, and thus for the antitumor activity of platinum(II) complexes.

The hydrolysis kinetics of platinum(II) complexes is dependent on the strength of the bond $(\mathrm{Pt}-\mathrm{X})$ between platinum and the leaving group $\mathrm{X}$, in our case chloride. By structural variation of the latter, the rate of hydrolysis and thus the extent of tumor inhibition can be influenced. However, it cannot be excluded that the amine ligands also exert an influence on the $\mathrm{Pt}-\mathrm{X}$ bond. Therefore we have used vibrational and NMR spectroscopies to study whether the strength of the $\mathrm{Pt}-\mathrm{Cl}$ bond changes with increasing ring size in dichlorobis(cycloalkylamine)platinum(II) complexes.

The influence of the cycloalkyl moiety on the electron density of the coordinated nitrogen atom may be deduced from the ${ }^{1} \mathrm{H}-\mathrm{NMR}$ spectra [5]. Cyclopropylamine requires separate consideration [5], to account for ring current effects due to the unusual $60^{\circ}$ bond angles in the three-membered ring. For the higher homologues, a growing number of carbon atoms in the cycloalkylamine residue results in a shift of the ${ }^{1} \mathrm{H}-\mathrm{NMR}$ resonance of the $\mathrm{NH}_{2}$ groups to lower ppm values, owing to an increasing shielding of the NH protons. This shielding is confirmed by 
SCAMP calculations for the pure amine ligands, which show negative charges on the $\mathrm{N}$ atom (i.e., $-0.325 \mathrm{e}_{0}$ for cyclopropylamine, $-0.332 \mathrm{e}_{0}$ for cyclobutylamine and cyclopentylamine, and $-0.335 \mathrm{e}_{0}$ for cyclohexylamine, cycloheptylamine, and cyclooctylamine, respectively) [5]. This effect should influence the electronic structure of the central platinum atom. However, extensive studies of the UV absorption and emission spectra of the complexes do not support this assumption [6]. The variation of the neutral ligands produces only a small effect on the electronic spectra of the Pt(II)-complexes. In accordance with this result IR and Raman spectroscopy yield comparable values for the frequency of the $\mathrm{Pt}-\mathrm{Cl}$ stretching vibration in the entire series [5]. All complexes exhibit an intense $\mathrm{PtCl}_{2}$ symmetric stretching band, with a maximum near $320 \mathrm{~cm}^{-1}$ and a half width of $\approx 25 \mathrm{~cm}^{-1}$. This means that the size of the cycloalkylamine ring does not entail significant differences in the $\mathrm{Pt}-\mathrm{Cl}$ binding strength. This result is in accordance with a kinetic study of Braddock et al. [2]. The authors found that, with the exception of cis-dichlorobis(cyclopropylamine)platinum(II), all homologues show comparable first-order rate constants for the solvolysis in DMSO $\left(3: k_{1}=17.4 \times 10^{4} \mathrm{~s}^{-1} ; 4-8\right.$ : $\left.k_{1}=9.2-6.6 \times 10^{4} \mathrm{~s}^{-1} ; 60^{\circ} \mathrm{C}\right)$. In this reaction an irreversible exchange of one chloride ligand by $D M S O$ is taking place. The complex with the least basic amine (3) proved to be significantly more labile than the others.

In view of these results, although we found no influence of the pure cycloalkylamine ligands on cell proliferation, it is obvious that the amine ligand (i.e. the non-leaving group) influences the cytotoxic activity of the homologous cis-dichlorobis(cycloalkylamine)platinum(II) complexes in another, still incompletely characterized way. Important information on this question is provided by physiochemical and biochemical studies of Butour et al. [21] on adducts of DNA with cis- $\left[\mathrm{Pt}\left(\mathrm{RNH}_{2}\right)_{2}\left(\mathrm{NO}_{3}\right)_{2}\right]$ (where $R$ represents $\mathrm{H}, \mathrm{CH}_{3}$, or cyclobutyl to cyclohexyl). These compounds, which are immediately transformed into the corresponding active $\left.>\mathrm{Pt}\left(\mathrm{H}_{2} \mathrm{O}\right)_{2}\right]^{2+}$ species under physiological conditions, exhibit quantitative reaction with DNA in less than $1 \mathrm{~h}$ at $37^{\circ} \mathrm{C}$ forming bifunctional adducts with adjacent nucleotides. In spite of their fast and comparable rate of quantitative reaction with DNA, these compounds show differences in their antitumor activities [22]. Presumably these differences are caused by a destabilization of the secondary structure of DNA which renders the DNA-protein interaction more difficult. The extent of destabilization depends on the size of the alkyl residue. The authors state that a disruption of DNA conformation by steric crowding of the non-leaving groups is unlikely. A hindrance of the solvation of DNA by the hydrophobic cycloalkyl residues is considered as an important aspect of drug action. These perturbations may have consequences for the antitumor activity; they might also be important for the inhibition of resistance development by the tumor cell.

In a comprehensive study, Braddock et al. [2] have shown that the trans-isomers of homologous cis-dichlorobis(cycloalkylamine)platinum(II) complexes (3-6) possess no substantial antitumor activity in the test on the ADJ/PC6 tumor of the mouse. These additional examples extend the original observation of Rosenberg [23] that only the cis-isomer of diamminedichloroplatinum(II) is active. Surprisingly, in our own experiments the comparative testing of the cis- and trans compounds of dichlorobis(cycloheptylamine)platinum(II) (7/9) and dichlorobis(cyclooctylamine)platinum(II) (8/10) on proliferating MDA-MB-231 breast cancer cells yielded nearly 
the same activity pattern for the related isomeric pairs. Comparable examples where the cis and trans isomers are similarly active were detected in the class of dichlorobis(pyridyl)platinum(II) complexes by Farrell et al. [24]. The compounds produced a weaker inhibition of the L1210 and P388 leukemia of the mouse than cisplatin.

Likewise, the rule that monofunctional platinum(II) complexes, which contain 3 amine ligands and only one leaving group such as $\mathrm{Cl}^{-}$, are inactive, has been disproved by Hollis et al. [25]. The authors showed that such complexes inhibit the growth of several tumor models, inspite of their ability to react only with one nucleophilic center of the DNA. [For a more extensive discussion of the structure activity-relationship of platinum(II) complexes, the reader is referred to reviews in the literature [26-30].]

The great differences in the antitumor activities of the stereoisomers of diamminedichloroplatinum(II) (cisplatin is a very potent drug, transplatin is ineffective) are attributed to a faster repair of the transplatin-DNA lesions [31-34]. The repair-resistant intrastrand crosslinks are formed by cisplatin but not by its trans isomer, for stereochemical reasons. Transplatin reacts exclusively with nucleotides in opposing DNA strands and forms interstrand crosslinks, which are also hardly accessible to repair [35]. However, the interstrand crosslinks are found with a lower frequency, which is a possible reason for the inactivity of transplatin against tumors [35]. It is believed that only the bifunctional adducts but not the monofunctional ones, which are primarily formed in the reaction of transplatin with DNA, can escape the repair by enzymes [29]. This assumption was confirmed by investigations of Bernges et al. [36, 37] on the repair of cis- and transplatin-treated DNA by $E$. coli DNA polymerase I. This enzyme contains DNA polymerase as well as exonuclease activity (i.e., proofreading and repair functions). In contrast to bifunctional $\mathrm{Pt}$-adducts (i.e. crosslinks), the monofunctional adducts which are preferentially formed by transplatin, are sensitive to degradation by this enzyme. Intrastrand crosslinks, especially between adjacent guanosine molecules, are not efficiently recognized and repaired. Therefore they accumulate in the DNA leading to the antitumor effect of cisplatin [33].

The surprising result of this study that trans-dichlorobis(cycloalkylamine)platinum(II) complexes with large 7- or 8-membered rings (compounds 9 and 10) possess inhibitory activities comparable to those of their cis-isomers (7 and 8), could be explained from the evidence summarized in the preceding paragraphs as follows. Most likely, mono- but not bis-adducts with DNA are formed by the trans configurated platinum(II) compounds 9 and 10. In these adducts, the bulky lipophilic non-leaving amine groups destabilize the secondary structure of DNA, and thereby the protein-DNA interactions. This perturbation should influence the recognition and the repair of platinum-DNA adducts of 9 and 10 (compare Refs. $[21]$ and [25]).

A more plausible reason for the remarkable antiproliferative (cf. Fig. 6A-D) and toxic (cf. Fig. 7B) potential of the higher dichlorobis(cycloalkylamine)platinum(II) homologues 7-10 appears to come from their high lipophilicity. Souchard et al., who have measured hydrophobicity parameters of the nitrato analogues of the complexes 4-7, found a striking discontinuity among this series [22]. If the relative 
hydrophobicity of the cyclobutylamine derivative is defined 1.0 , the corresponding values for the complexes containing the cyclopentyl, cyclohexyl and cycloheptyl moieties were 3.7, 6.3, and 23.0, respectively. In contrast to the work of Braddock et al. [2] who did not observe a correlation between lipophilicity and antitumor activity, our data seem to be consistent with this steep increase in lipophilicity: both, antiproliferative activity and "basal" toxicity against the MDA-MB-231 human breast cancer cell line parallel the increase of the hydrophobicities of the compounds 6 and 7.

Although it has been proposed that large lipophilic ligands might facilitate drug transport across cell membranes [22], lipophilicity appears to be a critical factor. In a previous study, our group has shown that extremely lipophilic platinum complexes of the 1,2-diphenylethylenediamine-type with stearate leaving groups are trapped in the lipid bilayer of erythrocyte ghosts [38]. As a consequence such compounds cannot react with DNA, generally agreed with as the main target of platinum anticancer drugs. Braddock and coworkers [2] have already doubted that all members of the homologue series of dichlorobis(cycloalkylamine)platinum(II) complexes have the same mechanism of action. Considering the preceding argumentation, it is conceivable that the marked antiproliferative activity of the compounds 7-10 results from a combination of effects as inhibition of DNA synthesis and interference with cell membrane integrity, as a function of platination of essential membrane constituents e.g. unsaturated fatty acids, surface and integral proteins. This hypothesis is supported by the experiments on static, non-dividing (i.e. there is no DNA synthesis) populations of MDA-MB-231 cells. Whereas cisplatin (its main mechanism of action is interference with DNA synthesis by the formation of bifunctional cross links) was only marginally toxic, the higher dichlorobis(cycloalkylamine)platinum(II) complexes caused disintegration of the cells. In contrast to Braddock et al. [2] who reported slightly higher toxicities for the isomers with trans geometry, our data clearly show that the trans-isomers are much less toxic (cf. Fig. 7B). The detection of these differences was achievable by using almost confluent cultures, since the extent of cytotoxicity is influenced by the cell density seeded [4], i.e. it increases with decreasing cell number. By conventional chemosensitivity assays (using low initial cell densities) gradual differences in toxicity will not be detected, since the resolution of these assays is limited by their high sensitivity, especially when drugs produce cytocidal effects. The reduced toxicity of the trans-isomers might be explained with the formation of monofunctional adducts with membrane constituents causing less damage to the cell.

Although the value of the higher dichlorobis(cycloalkylamine)platinum(II) complexes as potential anticancer drugs is compromised by their high "basal" toxicities, they can serve as useful tools for getting more insight into the mode of action of cisplatin analogues in further mechanistic studies.

\section{Acknowledgements}

Thanks are due to M. Zabel for the X-ray measurement, T. Burgemeister for recording the ${ }^{1} \mathrm{H}-\mathrm{NMR}$ spectra, J. Bernhard, R. Deser, and A. Prückl for recording the IR spectra, and A. Wokaun for carefully inspecting the manuscript. 


\section{References}

[1] Connors T. A., Jones M., Ross W. C. J., Braddock P. D., Khokhar A. R., Tobe M. L. (1972) Chem. Biol. Interactions 5: 415

[2] Braddock P. D., Connors T. A., Jones M., Khokhar A. R., Mack D. H., Tobe M. L. (1975) Chem. Biol. Interactions 11: 145

[3] Connors T. A., Cleare M. J., Harrap K. R. (1979) Cancer Treat. Rep. 63(9-10): 1499

[4] Bernhardt G., Reile H., Birnböck H., Spruß T., Schönenberger H. (1992) J. Cancer Res. Clin. Oncol. 118: 35

[5] Kritzenberger J., Zimmermann F., Wokaun A. Inorg. Chim. Acta (submitted)

[6] Kritzenberger J., Yersin H., Zabel M., Range K.-J. Inorg. Chim. Acta (submitted)

[7] Howard-Lock H. E., Lock C. J. L., Turner G., Zvagulis M. (1981) Can. J. Chem. 59: 2737

[8] Lippman M. E., Monaco M. E., Bolan G. (1977) Cancer Res. 37: 1901

[9] Reile H., Birnböck H., Bernhardt G., Spruß T., Schönenberger H. (1990) Anal. Biochem. 187: 262

[10] Hartley F. R. (1973) Chem. Soc. Rev. 2(2): 163

[11] Chatt J., Duncanson L. A., Venanzi L. M. (1955) Inorg. Subst. React. Part I: 4456

[12] Burdett J. K. (1977) Inorg. Chem. 16: 3013

[13] Kauffman G. B., Cowan D. O. (1963) Inorg. Synth. 7: 239

[14] Hicks C. P., Spiro M. (1985) React. Kinet. Catal. Lett. 29(1): 27

[15] Lock C. J. L., Zvagulis M. (1981) Inorg. Chem. 20: 1817

[16] Zanotti G., Del Pra A., Bombieri G., Tamburro A. M. (1978) Acta Cryst. B34: 2138

[17] Bradford J. P., Faggiani R., Lock C. J. L. (1981) Acta Cryst. B37: 243

[18] Cherchi V., Faraglia G., Sindellari L., Voltarel G., Siotran S., Furlani A., Ravalico L., Scarcia V. (1988) Platinum and other Metal Coordination Compounds in Cancer Chemotherapy, Martinus Nijhoff, Boston, p. 643

[19] Ha T. B. T., Souchard J.-P., Wimmer F. L., Johnson N. P. (1990) Polyhedron 9: 2647

[20] Bancroft D. P., Lepre C. A., Lippard S. J. (1990) J. Am. Chem. Soc. 112: 6860

[21] Butour J.-L., Alvinerie P., Souchard J.-P., Colson P., Houssier C., Johnson N. P. (1991) Eur. J. Biochem. 202: 975

[22] Souchard J.-P., Ha T. T. B., Cros S., Johnson N. P. (1991) J. Med. Chem. 34: 863

[23] Rosenberg B., Van Camp L., Trosko J. E.. Mansour V. H. (1969) Nature 222: 385

[24] Farrell N., Ha T. T. B., Souchard J.-P., Wimmer F. L., Cros S., Johnson N. P. (1989) J. Med. Chem. 32: 2240

[25] Hollis L. S., Amundsen A. R., Stern E. W. (1989) J. Med. Chem. 32: 128

[26] Cleare M. J., Hoeschele J. D. (1973) Platinum Metals Rev. 17(1): 2

[27] Sherman S. E., Lippard S. J. (1987) Chem. Rev. 87: 1153

[28] Lippert B. (1988) Gaz. Chim. Ital. 118: 153

[29] Lepre C. A., Lippard S. J. (1990) In: Eckstein F., Lilley D. M. J. (eds) Nucleic Acids and Molecular Biology, vol. 4. Springer, Berlin Heidelberg New York Tokyo p. 9

[30] Reedijk J. (1987) Pure \& Appl. Chem. 59(2): 181

[31] Alazard R., Germanier M., Johnson N. P. (1982) Mutat. Res. 93: 327

[32] Plooy A. C. M., van Dijk M., Lohman P. H. M. (1984) Cancer Res. 44: 2043

[33] Ciccarelli R. B., Soloman M. J., Varshavsky A., Lippard S. J. (1985) Biochemistry 24: 7533

[34] Roberts J. J., Friedlos F. (1987) Cancer Res. 47: 31

[35] Pascoe J. M., Roberts J. J. (1974) Biochem. Pharmacol. 23: 1345

[36] Bernges F., Holler E. (1988) Biochemistry 27: 6398

[37] Bernges F., Holler E. (1990) Eur. J. Biochem. 191: 743

[38] Koch M., Bernhardt G. (1991) J. Cancer Res. Clin. Oncol. 117 [Suppl.]: 104 